Psychology of Language and Communication 2012, Vol. 16, No. 3

VERSITMOPEN

DOI: $10.2478 / v 10057-012-0016-6$

\author{
ANNA CIERPKA \\ University of Warsaw
}

\title{
NARRATIVE IDENTITY IN LATE ADULTHOOD
}

\begin{abstract}
Narrative identity is recognized as a process and viewed in dynamic terms, as an entity subject to constant changes in the course of one's life. It is assumed that an increasing need to make changes in one's history of life emerges in middle adulthood. A generative script is revealed, containing a plan to become part of the lives of future generations. The process of creative integration of one's life story may gather momentum in late adulthood, when individuals explore their identity in the context of their life's work. In order to test the above assumptions, narratives of participants aged 65-80 years who were wives/mothers/grandmothers or husbands/fathers/grandfathers during their lives were analyzed. Six main themes characteristic of life stories in late adulthood were identified, along with groups of traits, behaviors and values which participants wished to pass on to subsequent generations. The narratives clearly featured a generative motivation and the need to integrate one's story.

Key words: narrative, personality, self-narratives, identity, ego integrity, adulthood
\end{abstract}

\section{Introduction}

According to lifespan psychology, human development is a lifelong process (Baltes, Reese and Lipsitt, 1980; Harwas-Napierała and Trempała, 2011). Adults have a persistent ability to develop through the mechanisms of individuation and self-understanding. Although late adulthood is the period of declining physical and psychological abilities, it is also the time when the remaining resources are put to use. Studies have shown that late adulthood can hardly be described as a stagnant phase. It is dominated by a strong aspiration to determine who we are and who we are becoming, and to give meaning to this stage of our lives (Staudinger, Schindler, 2002).

Address for correspondence: Anna Cierpka, University of Warsaw, Faculty of Psychology, Stawki 5/7, 00-183 Warsaw, Poland. E-mail: anac@psych.uw.edu.pl 
Growing interest in the period of late adulthood is associated with the shifting of demographics toward an increased share of elderly persons in the total population in developed countries (Straś-Romanowska, 2000). Consequently, the issue of identity of older adults is gaining in prominence. Recent studies on this period of development have focused on individual resources, opportunities for selffulfillment, and goal achievement (Staudinger, Schindler, 2002; Staudinger, 2005; Straś-Romanowska, 2000).

Her analysis of biographies of people in late adulthood has led C. Bühler (1999) to conclude that the dominant theme at the start of this period of life is self-fulfillment. It is the sense that life has value and that its main goals have been achieved. Thus, the essential question of this period of life is: Has my life added something to the general good, have I contributed to the progress of mankind? According to Bühler, a marked regression to the earliest stages of life and a focus on satisfying basic physiological needs emerges only as late as between 80 years of age and death. That is the time of preparing for the end, looking back at one's life, accepting the fact of imminent death and awaiting it.

Research conducted by Saup (1991, quoted in: Faltermaier, Mayring, Saup and Strehmel, 2002) brought evidence of profound changes in personality during late adulthood which expand the spectrum of behaviors and the depth of experience. New interests and activities emerge; lifestyle possibilities are expanded. Women aged 65-66 years asked to describe how their personality had changed in recent years mentioned a number of positive changes: $59 \%$ said their scope of interests had expanded; $39.6 \%$ claimed they felt free and experienced mostly positive emotions; $76 \%$ said they had a more positive outlook on life; $49.3 \%$ looked for new social contacts, and $50.7 \%$ had discovered new talents which expressed their personality.

Opportunities for personal development and integration in late adulthood are also prominent in the thought of E.H. Erikson (1980). This period coincides with the seventh stage of development and is characterized by a conflict between ego integration and despair. Ego integrity is defined as a state of mind characterized by proclivity for order and meaning. According to Erikson, achieving ego integrity is tantamount to discovering the meaning of life and assurance of finding one's own path in life. This is also associated with a sense of passing on, conveying one's experience to younger generations (Faltermaier, Mayring, Saub and Strehmel, 2002; Straś-Romanowska, 2005). At the opposite extreme of ego integrity is the state of despair, where individuals are unable to accept their lives and experience a sense of emptiness and loss. This is also associated with a sense of guilt and more intense fear of dying (Straś-Romanowska, 2005).

An event of particular importance for the further existence of individuals in late adulthood is retirement with its associated change in lifestyle and the need to redefine one's social and family relations. Equally important is fulfilling the role of grandparent and passing on one's experience to future generations. There 
is also the necessity to face the death of one's spouse, friends and acquaintances (Kielar-Turska, 2002).

In middle adulthood, narrative identity requires reworking due to changes in life perspective, "time already lived" and "time left to live." New themes include death, fleetingness and limited lifespan. A generative script emerges, containing references to the future and the life of generations to come (Oleś, 2002; Oleś, Puchalska-Wasyl, 2008). According to Tokarska (1999, p. 184), generativity is a type of personal immortality, extension of self into future generations by offering some of what we have accomplished to society. With age, the form of narrative also evolves, with "creative integration" gaining prominence (Oleś, 2002). In late adulthood, when looking back upon their life, people try to integrate various stories into a coherent whole. Now the goal is to come up with one, multi-thematic, coherent story which offers insight into changing fortunes, relations with others, tasks which have been accomplished and dreams never achieved (Oleś, 2008b, p. 50).

What, then, is the image of Self in the narratives of older adults? What is the content of the generational message included in their stories? Do all narratives indeed feature efforts to integrate one's life story? The present research attempts to answer these questions.

\section{Methods}

\section{Participants}

The sample consisted of 22 individuals aged 65-80 years, residing in Warsaw. All participants had a university education, used to be professionally active and were retired at the time of the study. They had performed three social roles in their lives: the women were wives, mothers and grandmothers; the men were husbands, fathers and grandfathers. Due to early withdrawal and requests to turn the voice recorder off, the study was ultimately completed by 20 participants.

\section{Procedures and instruments}

The study was usually conducted at the participants' homes or at the rehabilitation center where they were staying. Following a telephone conversation and after obtaining consent, the date of the meeting was arranged. The eligibility criteria referenced above were verified during the telephone conversation.

The study employed the narrative interview method developed by F. Schutze (1990) and Rosenthal (1990, 2003). The interview consisted of three phases: introductory phase, narrative interview proper, and conclusion phase.

In the introductory phase, participants were acquainted with the aims and assumptions of the study (analyzing life stories of people in late adulthood). They were also informed that a voice recorder would be used to record the conversation for the purposes of later analysis. Participants were assured that the study was completely anonymous and that the conversation would never be published in its 
entirety. Due to the specifics of the study, participants were asked to reconsider one more time if they wanted to be interviewed and talk about their life and family. They were also told that they could stop the conversation any time they wished, ask for a break or withdraw from the study.

The interview proper was initiated with the following general question: Each person is different, everyone has their own story; could you tell me the story of your life? If the participant asked for the question to be made more detailed, they were prompted to start recounting their life from any time they wished. Due to the focus on generative content, the next question was about the family of origin: The stories of our lives are closely related to the history of the family in which we were born. Could you recount the story of your family of origin? In cases where the participant had already partly told the story of their family while recounting their own life story, the question was modified to start with the following words: I realize you have already spoken about it, but.... During the conversation, the experimenter tried to follow the participant and maintain contact. For that reason, the question was sometimes adjusted stylistically to make sure participants felt they were being listened to. Under no circumstances was the sequence or content of the question altered.

In the conclusion phase, participants were thanked for taking part in the study, asked how they felt and whether they had found the conversation difficult. The experimenters tried not to leave the participant in a worsened mood. As part of "following the interviewee" and active listening, participants were allowed to show pictures, objects of sentimental value etc. Everything the participants said in those situations was recorded and taken into account during analysis.

The recorded narratives were transcribed and subjected to qualitative analysis.

\section{Analysis of narratives}

In order to find out which content appeared and recurred in all the narratives in the study, narrative themes were identified in the texts. These were in the form of short pieces of narrative, the length of a couple of sentences, one sentence, or even only part of a sentence. The themes identified in the texts were grouped into categories. The categories of themes were derived from the empirical material in the course of identifying the themes. They contain themes concerning the same subject matter. Ultimately, the analysis of self-narratives yielded six categories of themes which recurred in all the stories. These were subjected to content-wise and frequency analysis (Cierpka, 2000). Analysis of the material collected in the study also revealed a number of minor themes, found only in some of the narratives. These were not taken into account in the analysis of theme categories present in all the narratives.

The content analysis of the narratives identified four categories of generative transfer present in the stories of older adults. These were the words, parts of sentences and sentences referring to what a given participant would like to pass on to future generations or what has been passed on to him/her. 
Figure 1. Categories of themes

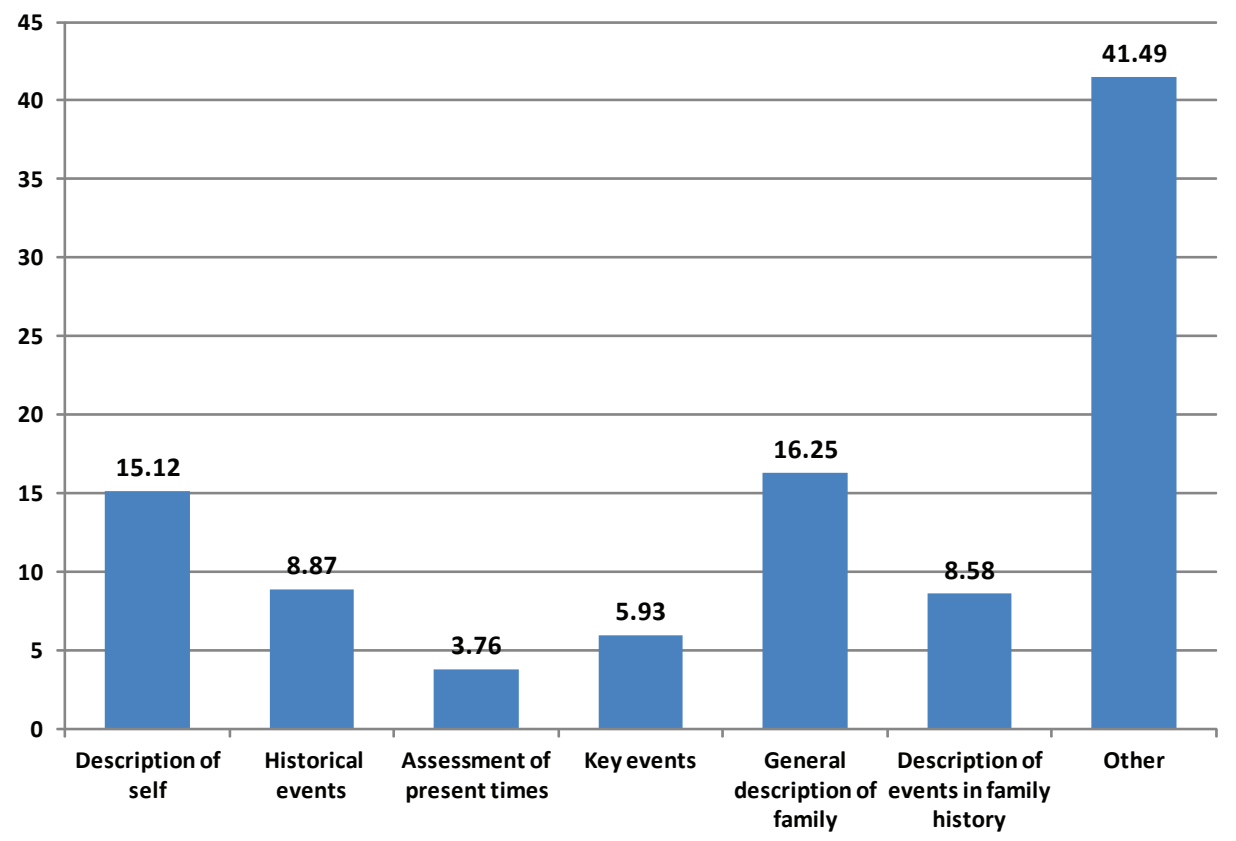

\section{Results}

The analysis of narratives collected in the study yielded six categories of themes which recurred in all the stories. Figure 1 presents the percentage share of themes in a given category in the narratives of people in late adulthood.

The sections below present a content-wise analysis of the identified themes.

\section{Description of self}

Description of self made up $15.12 \%$ of the narratives of older adults. In each case, the description of self was somehow enmeshed into "key events" (Rosenthal, 1995), which in the case of participants in this study included World War II and postwar historical events. On the one hand, these events can serve to reinforce continuity of one's own story, but on the other, they can also break it up, underlining its discontinuous nature. Self-narratives usually commenced by locating the "Self" within the context of wartime events:

Madam, I was 11 when the war began. I spent the whole of the Nazi occupation living with my parents and siblings in Ochota district in Warsaw. At the start of the Warsaw Uprising, I was still in Ochota, and since Ochota and Wola were the first districts to be evacuated and, as they say, finished their fight with the Germans, 
I was expelled, first transported to Zieleniak in Ochota, and then to Pruszkow, and from there I was shipped with my entire family, because by that time my father, brother and sister had returned from their Home Army group and met us at Zieleniak, and, you see, we were transported to a labor camp.... (Ms. A.)

The story of my life started before the war, three years before the war, that is in 1937, I can give you the date now, it no longer means anything. I was born in a family of craftsmen, my father was a carpenter, mother also worked, but then the tides of war swept us, or rather, upset our plans, because my father was enlisted, my mother counting that..., because we were living near the frontier 20 kilometers in Pomerania, 20 kilometers from the border between Poland and Germany and we had to run away, because we were afraid the Germans would occupy this place soon.... (Ms. U.)

As far as the events of WWII and the Nazi occupation are concerned, the narratives often contain summaries, reviews of lifelong achievements. There are reflections on life as a whole, assessed through the experiences from that period.

It is impossible to say in brief, but I could say that the war negated all my plans in life. My parents' house, we had a house, burned down. My daddy was killed in Dachau, shot, and I fought for 38 days in the Warsaw Uprising. After that Vlasov's men arrested me and took me to a concentration camp right on the frontline.... (Ms. B.)

I am a child of war. I was born in 1939, I lived with my mother in the Zamość region, there is this small town there, Tokarka. I was born in April, and the war broke out in September, so I was just a baby when my father went to war.... (Ms. D.)

The war turned my life upside down. I was born in Warsaw and I was in Warsaw during the Warsaw Uprising, living in the Wola district. It was horrible there. My father was shot at by those Germans, because me and my mother were meant to be taken to camp. We went to the transitional camp in Pruszkow, and from there, it was a stop on the way to Auschwitz.... (Mr. E.)

The "Self" is war, painful experiences, loss of loved ones and of meaning in life. The conclusion that "I am a child of war" seems to be the most adequate metaphor, an identity statement for the participants.

A lot of the material in the "description of self" category concerns the period of adolescence and early adulthood. This is consistent with reports from research on biographical memory, which found preference for memories from this period (Habermas, 2000; Maruszewski, 2005). Recounting one's own biography activates reflection on the question Who am I? Why is life worth living at all? These issues are particularly poignant in adolescence, which is why memories of that time may offer more answers to that question and as such tend to be actualized and recalled in self-narratives (cf. Habermas, 2000). It is also during adolescence and early adulthood that some things are experienced for the first time: the first kiss, first date, first exam, first job - which is why these events are likely to be salient in the memory and determine the characteristics of the Self, serving as a point of reference for other events (Maruszewski, 2005). 
...I attended the school in Ostrobramska street, near the Gate of Dawn. Then I passed the exam to junior high school, but I was really keen to get into the one managed by the Sisters of the Holy Family of Nazareth, because I loved the hats; I had to study in Lithuanian. My reading in Russian was poor, so it was tough to prepare, but I somehow did though I didn't know... (Ms. H.)

...I was a rebellious teenager...I had the craziest ideas... (Ms. W.)

...I was an unbearable boy, I was doing very poorly at school and I started smoking early, but the result was that I started early so I quit early, because I quit in 6th grade of primary school, which I was repeating for the first or second time, I can't remember exactly, because I had to repeat the 6th grade many times, but at least I memorized the material very well... (Mr. C.)

\section{Historical events}

The particular awareness of history in the "self description" category was present in practically all the narratives and appears to be a characteristic feature of the narratives of people in late adulthood (Staudinger, Schindler, 2002). Historical events are inculcated with special significance, being inserted into the story at every turn, as background for experience and a reference point for reflection on one's life. Older adults have witnessed history as it unfolded, and they can transfer that knowledge to future generations. The message is also unique because the narrator has actually lived through certain experiences and their accounts are emotional. "Historical events" constituted a large portion of material in the narrative analysis - as much as $8.87 \%$ (this category includes descriptions of historical events not incorporated in descriptions of oneself).

...That was the cover for a junior high school, Warsaw's well-known St. Stanislaw Kostka junior high; the school was established in 1907 ... The only one to have survived [the participant's school report], which is why it is in the museum, signed by the first headmaster and Count Wielkopolski, the founder of the school, the only one to survive the Nazi occupation. The only one, not because the marks were good, but because it survived and there are also publications and another item the size of this dossier, and the whole picture is taken this way. It is the only school report from the Nazi occupation in existence... (Mr. A.)

...those were hard times, the 1950s, ours was considered to be a kulak farm, which was persecuted by the system of that time, victimized, mandatory crop, meat, and I think milk donations were instituted, I no longer remember exactly... (Mr. D.)

...During World War I an aircraft was shot down over Żelechów, and the pilot was captured, because there were Russians in Żelechów, and the German pilot was captured by the Poles, the inhabitants, that is. He was wounded, so a certain Mr. $Z$ wolinski, which is also nicely described in a book, a pharmacist, gave him first aid, treated him and kept him until the war was over, and the pilot, I don't know how, but he returned safely to his family. And during World War II in 1939 suddenly there was this terrible bang, bombers flying and all the bombs dropped outside of town, 
the common greens, all the bombs. Our house was on the edge, so the windows were blown out. All the bombs were dropped there and that pilot wrote that his father on his deathbed said that if he was ever in the army, if you ever have to attack the town, he said, remember, these people saved my life and you have to remember that and protect them... (Ms. P.)

\section{Assessment of present times}

Quite often narratives of historical events contain a moral assessment. A number of personal attitudes and moral assessments appeared in the description of the present times; in fact, many more than in the descriptions of the past. This seems to be another characteristic feature of narratives told in late adulthood. Previous research (Lang, Neyer, Asendorpf, 2002) has shown that, compared with individuals in middle adulthood, people of this age demonstrate more pro-social behaviors and are more value-oriented. This is expressed in conclusions and references to events and actions of others that emphasize their ethical significance. The "Assessment of present times" category made up $3.76 \%$ of narratives.

...As far as young people are concerned, I have a lot of reservations with regard to how they are brought up today. They do not care about politics, about their country, about their families, but prefer to bum around the world. They take drugs, drink, this is a generation which simply horrifies us, old people... (Ms. B.)

...Because we know why, nowadays there are different sets of values, those who were dishonest are now considered to be very honest, because they have better possibilities, they are better off, financially. And nobody questions them, the issue of religion, yes, but from what we can see those who go to church return here and fight each other, brawl, this is different than it used to be, today gifts are so, this is a completely different lifestyle than before... (Mr. U.)

\section{Key events}

Besides the events of war and the occupation referenced above, which were important for the "Self", all the participants described key events in their lives regarding important life choices, mostly associated with their professional career and starting a family. They make up 5.93\% of the material.

...I finished primary school, secondary school, in 1956 I passed the secondary education final exam and that same year I started at the Pedagogical University of Gdansk, majoring in natural sciences. I was trying to get to the Technical University of Poznan, I graduated from that Pedagogical University, met my wife there... (Mr. U.)

...In 1947 I took the competitive exam at the Technical University of Warsaw, the Department of Mechanics, after graduation, in my case it was in 1953, I went there for 3 years, for my exile, it was in 1953 I started in that job, in 1956 my son was born... (Mr. W.)

...I started attending the Teachers College in Torun, I graduated, meanwhile I changed my work, went to a regular university and majored in pedagogy, I met 
my husband, we were married in 1964, I gave birth to our first child, then our second... (Ms. U.)

\section{General description of family}

Family is a particularly important reference group for older adults. Apart from considering starting a family to be one of the most important events in life, the family is the focus of the most attention in their narratives. A general description of family takes up as much as $16.25 \%$ of the text. On the one hand, this was probably influenced by the structure of the interview, but on the other, the participants' personal stories were deeply enmeshed in the stories of their families. Some participants focused on their parents in their descriptions, while others presented the whole family tree. Notably, women spoke more of their mothers, while men of their fathers.

...I lived with my mother at the far reaches of the Zamosc region, in the town of Tokarka. I was raised by my mom only, she never remarried. We lived in Szczebrzeszyn, my mom worked as a cook at the local vocational school. She was a very simple woman... (Ms. D.)

My mom was a very, very responsible and dynamic person. As children, we called her sheriff, she was a sheriff. She was in charge, we had to listen, and we all had our assigned tasks. She was strict with us. Mom was very practical. She could fight for her own, oh yes, she was a true diplomat. Whenever she had a problem, she would first ask, analyze, but always seek the advice of smart people. She analyzed all that, and then made her conclusions so as not to be worse off. She was so practical, she taught us to tell the truth and not become involved in any conflicts. She taught us to work hard. Whenever it was necessary, there was no discussion, we had to go to harvest, pick potatoes, even get a job early. My mother had workers for picking potatoes, we were already studying, we were very independent and frugal... (Ms. E.)

...My father was a carpenter, or rather they called him a cartwright, because he was a farmer, used to make carriages, chaises, hackneys, and later peasants' carts. He was born in Biala Podlaska, he was in fact, it was a manor and they lived there and my father was there and the landowner took a liking to him and taught him his job. That is, he constructed coaches, carriages and such. Well, later as the eldest son he was mustered in, and since they were on the Russian side, he got recruited to the Russian army. And he fought on the fapanese front, later on the Turkish front, and here in the Turkish front he was charged with an affront. And since he was Polish and he had a Polish unit under his command as captain... (Mr. Z.)

...My father had no secondary education, he worked in agricultural construction, designed without an education. He was very good at that, he designed village houses and structures. My mom had always been a housewife. Father never let her anywhere near his work. A patriarchal marriage... (Mr. U.)

...My family lived in Podlachia. They were nobility, the same as in The Deluge or With Fire and Sword [novels by the Polish writer Henryk Sienkiewicz], the so- 
called nobility ... . It was in Lithuania. They were impoverished nobility. Whenever it was needed, they would take to their swords and fall in battle. So I come from a family where my great-great-grandfather fought in the November Uprising. They say it was, he was in the picture in a cavalryman uniform, so he was fighting during Napoleon's time. His son, who fought in the January Uprising, fought near Ostroleka. He took part in the fanuary Uprising. I had two grandfathers. My father's father took part in the January Uprising. He was gravely wounded, was in recovery for some time, but died. My other grandfather, the father of my mother, came from the region of Bronice and took part in the fanuary Uprising there. Once the Uprising was over, he had to flee, otherwise he would have been deported to Siberia... (Mr. A.)

\section{Description of events in family history}

Besides descriptions of individual family members, the narratives also contain depictions of events in family life. Due to a certain distinctive quality of this material, and the historical context of the events depicted, a separate category of "Description of events in family history" was included. It accounts for $8.58 \%$ of the whole text. Again, a special emphasis on history emerges here as the characteristic trait of narratives told by older adults.

...In the Stalin era we had no window panes, no windows, no doors. They surrounded our house, they were throwing everything out, tearing everything down, looking for my father. And all that time my father was in the nearby school, only they didn't enter the school because there were classes going on... (Mr. D.)

...My parents' house burned down, Madam. May daddy was killed in Dachau, they shot him. I no longer had a father, he never came back. There was my mom, very ill, she was 42, it was the liver. She was 42, my sister was 11 when we got back. The house was burned down, we had no place to live, my mom slept on the floor at some people's house, my sister did not go to school. That's what life was like back then. There was nothing to return to, nothing. Meanwhile my husband came back from England from General Anders' army, and we got married... (Ms. A.)

The categories discussed above account for $58.51 \%$ of the analyzed texts. As for the remaining $41.49 \%$, it is not that the material cannot be grouped into themes, but rather that the themes appear sporadically or only in very few of the narratives. For example, the theme of "significant others" does not appear in all the narratives. In some narratives a lot of time is devoted to descriptions of friends, with references to historical events experienced together (in content-rich episodes), while in others there is no mention of them, as if the only significant others were family members. Similarly, only some participants talked about their current health, while others made no mention of it. Compared to other similar investigations (cf. e.g. Cierpka, 2011; Bidacha and Małek, 2011), the presence of such huge sections of material typical only for some narratives reflects the exceptional uniqueness of the stories recounted by people in late adulthood. Thus the results of the present study confirm the validity of the idiographic approach to research on older adults. 


\section{Generative transfer}

Examination of the content of generative transfer in the narratives of older adults in the study yielded four main categories.

First, participants described the characteristic traits passed on from generation to generation. These traits ensure family cohesion, determine intergenerational similarities, perhaps are the definitive aspects of family identity, ensuring their stability over time and across space, e.g.:

"we are all cheerful people"

"ambitious, very hard working (dad) and I have also always been responsible in my studies and my work, because I have always followed my father, looking over his shoulder, and when he was doing something, I knew what it was"

"so you, like grandma Ewa, you order everybody around, like she used to do"

"I see myself as I saw my father, I act the way he acts and at some point, when I think what to do, well, my dad also ... and I act the same. The mistakes I saw in my father, I keep finding in myself, and I do the same things"

"there are no taboo subjects in my family, no hiding things, you ask a question, you get the answer. This is what I think, and there is a discussion. It's the same with my daughter, she says there are no taboo subjects in her home, we tell one another everything, explain, promote good values with our own behavior"

Second, there are descriptions of recurring life choices. This category comprises all aspects regarding the choice of field of study, career, similar life paths, decisions about one's life.

"he got admitted to the university, he graduated from the University of Physical Education (like his mom)"

"It is still like that in our family, they wanted to work in scouting (like their mom)"

"I had three children, and they all graduated from the Technical University, like me. My two sons and my daughter, they are all engineers. Johnny has just passed his final exam of secondary education and is planning to go the Technical University"

"I come from a family where my great-great-grandfather fought in the November Uprising. His father was fighting back in the Napoleon era. His son, who fought in the fanuary Uprising, fought near Ostroleka. My father's father took part in the fanuary Uprising. My other grandpa took part in the fanuary Uprising [the participant fought in the Warsaw Uprising]

When describing themselves, older adults tend to focus on those aspects of their biographies which are associated with family and give a sense of belonging. Emphasizing common traits, life choices and certain rituals is an important aspect of self-narratives. It seems that how a family maintains its identity for multiple generations is not just through loyalty (Boszormenyj-Nagy, 1973), but also the family ethos passed on from one generation to the next (Dryll and Cierpka, 1997). It is that ethos which determines the uniqueness, specifics of a given family, it is 
the system of meanings important for that family, affording a sense of belonging and of having an individual story rooted in the story of the family.

The third category covered the "wisdom of experience," all recapitulations and advice on what things in life are worth doing and how they should be done. Wisdom of experience refers to attitudes toward others, based mostly on respect and consideration for the dignity of another human being.

"...we have to look at the way people are brought up, the way young people are raised, first we need to help them, and only then draw conclusions about others; what I always say and what my parents taught me is that I have no right to judge others"

"this respect, dignity, you can never humiliate anyone, so that children respect others, whoever they may be; each person is different, and whoever they are, they are human beings, and that should be respected"

"we should help others, and help them a lot; it's worth being a good person; kind to others, trying to protect the weak"

"I have always said, listen child, you must see the value of the other person. Not everything is good, in you or in others, just think. You don't have to love them, even though they are often your enemies in one way or another"

"respect for others and willingness to listen to them; being sensitive and open to others; if someone comes to you, share what you have with them, food, drink, whatever, because you cannot let anyone go thirsty or hungry if you have anything, and if you have anything you do not need and you see someone else wants it, give it to them"

These wisdoms, passed on between generations, have a clear emphasis of values: respect for others, sensitivity and openness, honesty, kindness, and love. Generative transfers in this category also refer to the value of the family, its importance and priority status:

"...she is now retired and she takes good care of me, she is looking after me, because that's how it is in a family"

"family is more important than ambitions"

"I still think that you have to talk with your children and say: listen, we are making this much, daddy earns this much, mommy this much, so what do you think we need to buy, let's think together. Mom and dad used to discuss that with us, and then they did what they thought was best, but we felt important, because we were needed at every moment, at all times"

"my generation was somehow so emotional; one should listen to their parents and worship them, they are the greatest good; home, family, this is in my opinion the foundation of our existence. Without it, it is as if we didn't exist. If that disappears, the whole of humanity will perish with it"

The final category refers to religious and patriotic values passed on from generation to generation.

"we were simply raised Catholics, we are Poles, we have to preserve our Polish traditions" 
"a woman will be saved by bearing children; it is a wheel of sorts, and it is spinning; a baby won't let you sleep, an older one won't let you eat, and a grown one won't let you live"

"it is important to be Polish, we were raised in a very religious atmosphere ..., so that they are religious, that they follow the Catholic faith"

Each of the identified categories of generative transfer is associated with specific values. According to anthropologists, everyone has a natural need to define themselves with respect to universal or absolute values. These values and norms determine the rules of community life and ensure public order (Straś-Romanowska, 2010)."Imperative values and norms are the foundation of an atmosphere of honesty and trust so vital in human relations, the basis for ethos which cannot be replaced by even the most ideal laws; they are also the source of the uniquely human, subtle experience of a sense of dignity and honor. ... Late in our lives, we are reminded of values and fundamental rules by religious tales, wise books, moral codes (e.g. the Ten Commandments), as well as the writings of thinkers, great writers, philosophers and spiritual leaders"(op. cit., 2010, p. 31). People in late adulthood are at the highest level of moral development, finding a balance between egoism, responsibility and concern for others. Feeling responsible for future generations, they try to convey to them the permanent, timeless values, the basic truths which protect us from succumbing to the chaos of existence. This is perhaps an attempt to return to the so-called "grand narratives" (Lyotard, 1997, quoted in: Straś-Romanowska, 2010) which present a coherent description of the world and absolute values (the transcendentals).

\section{Conclusion}

The narratives of people in late adulthood provide fascinating material for exploring the mental life of their authors while revealing its uniqueness and depth. When narrating the story of their life, older people refer to historical and political events, offer colorful descriptions of facts and episodes remembered from their past experience. The key reference point is World War II and accompanying events. It is surprising that some people who experienced WWII as small children describe themselves as children of war. Others who lived through that period as adolescents or young adults remain strongly affected by those events. Listening to their stories gives the impression that they still live within that time, as if whatever happened after World War II and the Warsaw Uprising did not have the same significance. There is a striking sense of history: autobiographies are blended with the historical background, forming a kind of semantic whole, a historical "Self".

In recounting the stories of their lives, older adults search for their roots: they compare themselves to their parents, grandparents, looking for similarities, parallel paths, life and moral choices. They see similar character traits, behaviors and values in their children and grandchildren. The family emerges as a unit with well-defined 
identity, features that tell it apart from other families. It is an important reference point, a foundation for the "Self".

The narratives of people in late adulthood are infused with generative transfer, in a large part concerning values and references to what is truly important in life. They are also full of moral evaluations, both of historical events and current developments. They feature a kind of shift from "minor to grand narratives," combining individual resources with the intersubjective body of knowledge. This attempt to recapitulate one's life's work is a way to find its meaning. It can also provide a stimulus to merge a variety of stories into one semantic whole: with a coherent life-story a person can make sense of the course of their life and relations with other people (Oleś, 2008b). The meaning of life is not an easy term to operationalize, which is why empirical science, unlike philosophy, has devoted little attention to investigating the meaning and essence of this term. The meaning of life can be compared to internal order, ego integrity, which affects the well-being of people in the period of late adulthood (Kielar-Turska, 2002). Thus, the integration of one's own story, helping one to realize the moral and sense of one's life and to pass on this wisdom to future generations appears to be the most important task to be accomplished in late adulthood. "Non omnis moriar" woven in the history of individual lives.

\section{References}

Baltes, P.B., Reese, H.W., \& Lipsitt, L.P. (1980). Life-span developmental psychology. Annual Review of Psychology, 31, 65-110

Bidacha, M. \& Małek, K. (2011). Tożsamość narracyjna osób doświadczających choroby zagrażającej życiu [The narrative identity of people with life-threatening diseases]. In M. Straś-Romanowska, B. Bartosz, \& M. Żurko (Eds.), Psychologia matych $i$ wielkich narracji [The psychology of minor and grand narratives] (pp. 329-352). Warszawa: Eneteia.

Bühler, C. (1999). Bieg życia ludzkiego [The course of human life]. Warszawa: Wydawnictwo Naukowe PWN.

Cierpka, A. (2000). Metody analizy narracji w badaniach psychologicznych [Methods of narrative analysis in psychological research]. In M. Straś-Romanowska (Ed.), Metody jakościowe w psychologii wspótczesnej [Qualitative methods in modern psychology] (pp. 129-139). Wrocław: Wydawnictwo Uniwersytetu Wrocławskiego.

Cierpka, A. (2011). Tożsamość narracyjna młodzieży a relacje w rodzinie [The narrative identity of young people vs. family relationships]. In E. Dryll \& A. Cierpka (Eds.), Psychologia narracyjna. Tożsamość, dialogowość, pogranicza [Narrative psychology. Identity, dialog, borderlands] (pp. 149-166). Warszawa: Eneteia.

Erikson, E.H. (1980). Identity and the life cycle. New York-London: W.W. Norton \& Company. 
Faltermaier, T., Mayring, P., Saup, W., \& Strehmel, P. (2002). Entwicklungspsychologie des Erwachsenenalters. Stuttgart: Kohlhammer.

Habermas, T. \& Bluck, S. (2000). Getting a life: The emergence of the life story in adolescence. Psychological Bulletin, 126, 748-769.

Harwas-Napierała, B. \& Trempała, J. (Eds.) (2011). Psychologia rozwoju człowieka. Charakterystyka okresów życia człowieka [Psychology of human development. Characteristics of different periods in human life]. Warszawa: Wydawnictwo Naukowe PWN.

Kielar-Turska, M. (2002). Rozwój człowieka w pełnym cyklu życia [Human development throughout the life cycle]. In J. Strelau (Ed.), Psychologia. Podręcznik akademicki. Tom I. [Psychology. University textbook. Vol. 1] (pp. 285-332). Gdańsk: GWP.

Kruse, A. (2005). Biografische Aspekte des Alterns - Lebensgeschichten und Diachronizität. In S.H. Filipp \& U.M. Staudinger (Eds.), Entwicklungspsychologie des mittleren und höheren Erwachsenalters (pp. 3-34). Göttingen: Hogrefe Verlag.

Maruszewski, T. (2005). Pamięć autobiograficzna [Autobiographic memory]. Gdańsk: GWP.

Oleś, P. (2002). Rozwój osobowości [Development of personality]. In B. HarwasNapierała \& J. Trempała (Eds.), Psychologia rozwoju człowieka. Tom III [Psychology of human development. Vol. 3] (pp. 131-177). Warszawa: Wydawnictwo Naukowe PWN.

Oleś, P. (2008b). Autonarracyjna aktywność człowieka [Human self-narrative activity]. In B. Janusz, K. Gdowska, \& B. de Barbaro (Eds.), Narracja. Teoria $i$ praktyka [Narrative. Theory and practice] (pp. 37-52). Kraków: Wydawnictwo Uniwersytetu Jagiellońskiego.

Oleś, P. \& Puchalska-Wasyl, M. (2008). Teoria narracyjnej tożsamości Dana P. McAdamsa [Dan P. McAdams' narrative identity theory]. In P. Oleś \& A. Batory (Eds.), Tożsamość i jej przemiany a kultura [Identity and its changes vs. culture] (pp. 247-278). Lublin: Wydawnictwo KUL.

Rosenthal, G. (1990). Rekonstrukcja historii życia. Wybrane zasady generowania opowieści w wywiadach biograficzno-narracyjnych [Reconstructing a life story. Selected principles of generating stories in biographical narrative interviews]. In J. Włodarek \& M. Ziółkowski (Eds.), Metoda biograficzna w socjologii [The biographical method in sociology] (pp. 97-112). Poznań: Państwowe Wydawnictwo Naukowe.

Rosenthal, G. (2003). The healing effects of storytelling: on the conditions of curative storytelling in the context of research and counseling. Qualitative Inquiry, 9 (6), 915-933.

Schutze, F. (1990). Presja i wina: doświadczenia młodego żołnierza niemieckiego w czasie drugiej wojny światowej i ich implikacje biograficzne [Pressure and guilt. The experiences of a young German soldier in World War II and their biographical implications]. In J. Włodarek \& M. Ziółkowski (Eds.), Metoda 
biograficzna $w$ socjologii [The biographical method in sociology] (pp. 325-340). Warszawa: PWN.

Staudinger, U.M. \& Schindler, I. (2002). Produktiver Leben im Alter I: Aufgaben, Funktionen und Kompetenzen. In R. Oerter \& L. Montada (Eds.), Entwicklungspsychologie (pp. 955-982). Weinheim: Beltz Verlage.

Staudinger, U.M. (2005). Lebenderfahrung, Lebenssinn und Weisheit. In S.H. Filipp \& U.M. Staudinger (Eds.), Entwicklungspsychologie des mittleren und höheren Erwachsenalters (pp. 739-761). Göttingen: Hogrefe Verlag.

Straś-Romanowska, M. (2000). Późna dorosłość. Wiek starzenia się [Late adulthood. Old age]. In B. Harwas-Napierała \& J. Trempała (Eds.), Psychologia rozwoju człowieka. Tom II [Psychology of human development. Vol. 2] (pp. 263-292). Warszawa: Wydawnictwo Naukowe PWN.

Straś-Romanowska, M. (2005). Jakość życia w świetle założeń psychologii zorientowanej na osobę [Quality of life in the light of person-oriented psychology]. Kolokwia Psychologiczne, 13, 262-274.

Straś-Romanowska, M. (2010). Psychologia wobec małych i wielkich narracji [Psychology in the face of minor and grand narratives]. In M. Straś-Romanowska, B. Bartosz \& M. Żurko (Eds.), Psychologia matych $i$ wielkich narracji [The psychology of minor and grand narratives] (pp. 21-40). Warszawa: Eneteia.

Tokarska, U. (1999). W poszukiwaniu jedności i celu. Wybrane techniki narracyjne [In search of unity and goals. Selected narrative techniques]. In A. Gałdowa (Ed.), Wybrane zagadnienia z psychologii osobowości [Selected issues of the psychology of personality] (pp. 169-204). Kraków: Wydawnictwo UJ. 